UDC 334.027

DOI: https://doi.org/10.32840/1814-1161/2020-5-11

Lytvynenko Alina

$\mathrm{PhD}$ in Economics,

Associate Professor of the Department of Enterprise Economics and Management

S. Kuznets Kharkiv National University of Economics ORCID: https://orcid.org/0000-0003-0372-5130

Литвиненко А.О.

кандидат економічних наук, доцент, доцент кафедри економіки підприємств і менеджменту Харківського національного економічного університету імені Семена Кузнеця

\title{
TECHNOLOGIES DEVELOPING CRITICAL THINKING MODERN ENTREPRENEUR
}

\section{ТЕХНОЛОГІЇ РОЗВИТКУ КРИТИЧНОГО МИСЛЕННЯ СУЧАСНОГО ПІДПРИЄМЦЯ}

The article presents methodological recommendations for research in the field of solving new problems arising from decision-making. The ability to perceive information critically becomes necessary condition to protect a person from adverse psychological impact of information aimed at manipulating a person. The study of the content of the concept of "critical thinking" in its historical development is carried out, the content of key concepts is determined and the experience of applying the technology of developing critical thinking among students is analyzed. It should be noted that the developed techniques for developing critical thinking can be used not only among students of higher educational institutions, but also in business in general, taking into account the age characteristics of all participants.

Keywords: thinking, critical thinking, creativity, technology of critical thinking development, information.

У статті представлено методичні рекомендації щодо досліджень в області вирішення нових проблем, що виникають в результаті прийняття рішень. Уміння критично сприймати інформацію стає необхідною умовою для захисту людини від несприятливого психологічного впливу інформації, спрямованої на маніпуляцію особистістю. Здоровий спосіб життя сьогодні визначається не тільки режимом харчування, праці і відпочинку, але і захищеністю людини від негативного психологічного тиску. Тому значимість здоров'я-зберігаючих технологій сьогодні набувають ті технології, які сприяють розвитку критичного мислення у студентів вищого навчального закладу. Обгрунтовано зміни у всіх підсистемах дидактичної системи навчання, що забезпечують розвиток критичного мислення підприємця. Проведено дослідження змісту поняття «критичне мислення» в його історичному розвитку, визначено зміст ключових понять і проаналізовано досвід застосування технології розвитку критичного мислення у підприємців. Слід зазначити, що розроблені прийоми з розвитку критичного мислення можна використовувати не тільки у студентів вищих навчальних закладів, а й взагалі у підприємницькій діяльності, з огляду на вікові особливості всіх учасників. Запропоновано розуміння перевірки вихідних гіпотез, а також був використаний комплекс дослідження методів, що включає теоретичний аналіз загальної та спеціальної літератури з психології та фрізіології, (пов'язаної з проблемою дослідження), психодіагностичні методики, спостереження, бесіда, методи математичної статистики по обробці експериментальних даних, якісний аналіз результатів роботи. Обгрунтовано, що високі показники креативності можуть бути обумовлені як продуктивним процесом, так і високою мотивацією досягнень, компенсаторними механізмами, специфічністю одержуваної інфрормації. На основі отриманих даних про впровадження технологій розвитку критичного мислення можна відзначити необхідність розробки системи використання прийомів технологій розвитку критичного мислення. Достовірність і обгрунтованість отриманих висновків забезпечується повнотою зробленого теоретичного огляду, достатній обсяг вибірок, тривалістю спостереження, внутрішньої несуперечливості даних, отриманих в дослідженнях.

Ключові слова: мислення, критичне мислення, креативність, технологія розвитку критичного мислення, інфрормація. 
В статье представлены методические рекомендации для проведения исследований в области решения новых проблем, возникающих в результате принятия решений. Умение критически воспринимать инфрормацию становится необходимым условием для защиты человека от неблагоприятного психологического воздействия инфрормации, направленной на манипуляцию личностью. Обоснованно изменения во всех подсистемах дидактической системы обучения, обеспечивающих развитие критического мышления предпринимателя. Проведено исследование содержания понятия «критическое мышление» в его историческом развитии, определено содержание ключевых понятий и проанализирован опыт применения технологии развития критического мышления у студентов. Следует отметить, что разработанные приемы по развитию критического мышления можно использовать не только у студентов высших учебных заведений, но и вообще в предпринимательской деятельности, учитывая возрастные особенности всех участников.

Ключевые слова: мышление, критическое мышление, креативность, технология развития критического мышления, информация.

Problem statement. The scientific problem is that critical thinking is a common center for general and objective thinking, characterized by awareness, independence, reflectivity, purposefulness, validity, controllability and self-organization.

Purpose of the study is to substantiate the peculiarities of forming critical thinking technologies in modern conditions.

Overview of recent research and studies. The modern term "critical thinking" has its roots in ancient critical techniques. The well-known critical method of Socrates is based on teaching students to reasonably substantiate their position (decision), as well as on critical perception of information offered by other people. The technique of Socrates' question-and-answer procedures became the basis for creating "organon" by Aristotle, which later became known as "logic".

During the Middle Ages, burdened by the dogmas of church education, "critical technique" did not find development and application, but the attention of the thinkers of the Renaissance was again turned to the ideas of antiquity. So, M. Montaigne argued that forming and developing critical thinking is much more important to form child's personality than giving him a certain body of knowledge.

The era of the Reformation essentially merged with the Renaissance, but, leading the CounterReformation, the Jesuit Order revived the medieval, religious-authoritarian essence of pedagogy. The use of "critical technology" in the given historical conditions turned out to be impossible. This leads to a completely logical conclusion that critical technology in education is in demand only in a society based on democratic ideals, and it is completely denied in conditions of authoritarianism, when the development of a freethinking personality is not expected.

The Age of Enlightenment, brought by social changes in society, brings back the ideas of humanism. The idea of developing "critical technique" was reflected in the works of famous thinkers of that time. So, Rene Descartes focused on strengthening the work of the teacher, aimed at developing "students' ability to judge independently and correctly comprehend their own actions and the world around them" [1].

The pedagogical concept of Jan Amos Comenius, formed under the influence of Antiquity, Reformation, Renaissance, is based on the idea of proclaiming such basic components of the pedagogical process as understanding, will and activity of the pupil [1].
The ideas of developing critical thinking were reflected and further developed in the works of I. Kant "Critique of Pure Mind" [2], "Critique of Practical Mind", "Critique of the Ability of Judgment" which revived the interest of researchers to the problem [3].

At the beginning of the 20th century, the new paradigm of upbringing emerged, based on in-depth attention to the individual. This direction received special development on the basis of the pedagogy of pragmatism or progressivism, the leader of which was D. Dewey. The scientist advocated the practical orientation of education. According to D. Dewey, the aim of education is to form independent, or, in Dewey's terminology, "reflective thinking" [4]. The concept of reflective thinking was the basis to form the concept of critical thinking. G. V. Sorina notes that in 1919, when D. Dewey published his reflections in the book "How We Think", the ideas of critical thinking were not in demand. Only in the last decades of the XX century the idea of forming critical thinking has been developed [5].

But, if D. Dewey's ideas did not receive development in pedagogy for almost the entire century, then they were in demand in forming humanistic psychological school in the United States. One of the leaders in this area was K. Rogers who formulated the main ideas, principles of humanistic psychology which later became the basis for developing technology to develop critical thinking [6].

The idea of D. Dewey was developed by L.S. Vygotsky: "... in teaching it is much more important to teach a child to think than to give certain knowledge to him" [7]. Consequently, the educational process cannot be reduced to the transmission of ready-made knowledge by the teacher. Information assimilated without analyzing it, comparing it with other information obtained from alternative sources, becomes formal knowledge that has no outcome in a person's everyday life. In other words, in the learning process, it is necessary to discuss different points of view on the problem under study.

An important stage in the developing idea of critical thinking was the critical rationalism of $\mathrm{K}$. Popper, one of the greatest theorists and practitioners of criticism and critical thinking of the 20th century. According to Popper, the ideas of critical thinking are inseparable from the ideas of critical rationalism and criticism, the freedom of which he identified with the freedom of thought. One cannot but agree with his statement about the identity of critical thinking and a person's ability to reason [8]. Critical rationalism, according to Popper, is the most important tool for building an open society, the essential features of 
which are: critical analysis, joint discussion and focus on the capabilities of one's own intelligence [5].

K. Popper's theory of the open society describes the society of people of different views who live in harmony. The basis of relationships in such a society is the rational-critical attitude. S. I. Zair-Bek believes that "The popularity of the ideas of the open society nowadays enhances the importance of pedagogical innovations associated with this idea" [9].

K. Popper's views lay the foundation to form positive psychological background for developing critical thinking and forming a culture of criticism. The scientist claims that "the rationalistic approach takes into account, first of all, the evidence but not the personality of the proving person" [10].

The ideas of L.S. Vygotsky and K. Popper had a great influence on further research in the field of the psychology of thinking. The continuity of ideas was reflected in the works of $D$. Bruner, the basis of which was the conviction that mental development proceeds not as spontaneous maturation but in the process of learning and extensive use of active practical experience. In his work "The Culture of Education" he directly points to the urgent need to shift the emphasis in goal-setting from the knowledge component to the development component, highlighting the development of critical thinking. It is critical thinking, which in this work is figuratively called the "sieve of rational criticism", that underlies the independence of thinking [11].

Highlighting previously unresolved parts of a common problem. In 1956 B. Bloom proposed taxonomy of pedagogical goals in the cognitive sphere, within which he identified the levels of educational goals. There are only six of them and the "level of knowledge" is the first, that is, the initial level. Of course, thinking must have a foundation - the subject of reflection. But further levels contribute to the deep mastering of knowledge and development of personality: understanding, application, analysis, evaluation, synthesis. It was the levels of educational goals identified by B. Bloom that formed the basis to create the stages of technology to develop critical thinking. The taxonomy of B. Bloom, combining the ideas of many scientists, was the stage in the development of scientific thought, on the basis of which it became possible to create techniques and methods of teaching.

During the research, the following system of key terms was formed, which is provided in Table 1.

Table 1

Key terms and their most important derivatives

\begin{tabular}{|l|c|}
\hline \multicolumn{1}{|c|}{ Key terms } & The most important derivatives \\
\hline Thinking & Critical thinking \\
\hline \multirow{4}{*}{ Information } & Information field \\
\cline { 2 - 2 } & Information security \\
\cline { 2 - 2 } & Information culture \\
\cline { 2 - 2 } Technology & Information space \\
\cline { 2 - 2 } & Pedagogical technology \\
\hline
\end{tabular}

Statement of the main research material. The question of what is thinking is one of the central philosophical questions, the awareness of which is necessary to represent any intellectual activity. In scientific works, there are many definitions of this concept (Table 2).

In colloquial speech, critical thinking is usually synonymous with evaluating something negatively. The scientific understanding of critical thinking differs sharply from the trivial everyday understanding.

V.A. Bolotov: "Critical thinking does not mean the negativity of judgments, but a reasonable consideration of a variety of approaches and philosophies in order to make informed judgments and decisions" [16].

S.L. Rubinstein: "Criticality is an essential sign of a mature mind. The critical mind carefully weighs all the arguments for and against its hypotheses and subjects them to a comprehensive test" [17].

S.I. Zair-Bek: "... thinking is evaluative, reflective. It is an open thinking, not accepting dogmas and developing by imposing new information on personal life experience" [9].

D.Dewey: "The essence of critical thinking is delayed judgment; and the essence of this delay is the investigation of the nature of the problem before attempting to solve it" [4].

D. Kluster worked in Czech Republic and Armenia in the framework of the international project "Development of critical thinking through reading and writing" [18]. His characterization of the process defined by the term "critical thinking" is based on the opposition of different types of thinking. According to D. Kluster's views, memorization, understanding and creative (intuitive) thinking are "uncritical". However, creative thinking inherent in artists, musicians, scientists cannot be equated with reasonable reflexive thinking, because, relying on complex mental operations in their work, creative people do not always fully realize them [19].

There are no discrepancies about memorizing and understanding as a perception of what someone else has done, but many authors of scientific research equate creative thinking with critical thinking. For example, A.V. Fedorov introduces the term "critical creative thinking" [20].

An attempt to resolve the contradiction in views on the concept of critical thinking is found in S.I. ZairBek, who considers Critical thinking to be the basis for developing creative thinking [9].

Based on the presented approaches to understanding the concept of "critical thinking", it can be concluded that auxiliary concepts that reveal its essence and are used by different authors of scientific research can be combined into three logical groups located in a certain sequence reflecting the process of critical thinking (Table 3).

The stages of learning based on the technology of developing critical thinking are based on these three groups of terms. The development of critical thinking is possible through the use of information; therefore the term "information" is the key term for this study.

The definition of the concept of "information" was formulated by A.A. Zhurin: "Information - is information about the surrounding world and the processes taking place in it, perceived and interpreted by a person or special devices" [21]. 
Based on the analogy with physical fields, the aggregate of information existing in the world is called an information field. The accessible part of the information field for a specific person, corresponding to his personal and professional interests, forms the information space. Scientifically inaccurate information can be used to form motivation to acquire new knowledge, develop skills in using knowledge, and analyze the degree of understanding of the studied material. Today, there is no doubt that the ability to work with information is one of the priority skills for a modern person, a necessary component of information culture.

In S.I. Ozhegov's dictionary the following definition of the concept of "technology" is given: "it is a set of production processes in a particular industry, as well as a scientific description of production methods" [12]. Thus, this is a term for the production sphere, where it is possible to gradually regulate activities to achieve a result.

Discussions are underway around the concept of "pedagogical technology", and so far there is no consensus on the definition of this concept. G. K. Selevko, based on the analysis of definitions existing in the pedagogical literature, identifies three aspects of pedagogical technologies: scientific, procedural-descriptive and procedural-effective [22]. However, the definitions given by him completely coincide with the definitions of general didactics, private didactics and private methods. Consequently, pedagogical technology is a synthesis of the achievements of pedagogical science and practice.

Within the framework of this study, it is not considered relevant to discuss the classification of existing pedagogical technologies; it is quite fully presented in the textbook by G.K. Selevko [22]. However, meaning that the development of critical thinking is most effectively implemented on the basis of personalityoriented technologies, let's turn purposefully to the definition of this concept.

According to G.K. Selevko, personality in the technology of personality-oriented learning is not only a subject, but also "a priority subject, the goal of the educational system but not a mean of achieving any abstract goal" [22].

The technology development is based on the theoretical provisions of pedagogy and psychology of the late 20th century. I. V. Mushtavinskaya, T. Hofreyter, M. Monroe, T. Stein [25; 26] agree that the taxonomy of educational goals of B. Bloom was for the development of technological methods.

Since the technology for developing critical thinking determines the stages of the activity of not only students, but also the teacher, the role of the latter is undergoing significant changes (Figure 1).

Analysis of definitions of the concept "thinking"

\begin{tabular}{|c|c|c|}
\hline Author & Definition & Relevance to this study \\
\hline $\begin{array}{l}\text { I. Ozl } \\
\text { xplan } \\
\text { ctiona }\end{array}$ & $\begin{array}{l}\text { inking" is a person's ability to reason, which } \\
\text { a process reflection of reality, ideas, concepts, } \\
\text { ective in judgments" [12]. }\end{array}$ & \multirow{2}{*}{$\begin{array}{l}\text { The most important is considered an indication of } \\
\text { the fact that thinking, as a process of reflecting } \\
\text { the objective world, is possible only when solving } \\
\text { specific problems. } \\
\text { Hence, two important conclusions for pedagogical } \\
\text { activity follow: } \\
\text { - first, developing study of academic disciplines; } \\
\text { - secondly, thinking develops only in the process } \\
\text { of activity. }\end{array}$} \\
\hline $\begin{array}{l}\text { T. Frolov } \\
\text { hilosophical } \\
\text { ictionary }\end{array}$ & $\begin{array}{l}\text { "Thinking is an active process of reflecting the } \\
\text { objective world in concepts, judgments, theories, } \\
\text { etc., associated with the solution of certain } \\
\text { problems, with generalization and methods of } \\
\text { mediated cognition of reality" [13]. }\end{array}$ & \\
\hline $\begin{array}{l}\text { M. Kodzhaspi- } \\
\text { va Dictionary } \\
\text { Pedagogy }\end{array}$ & $\begin{array}{l}\text { characterized by a } \\
\text { reflection of reality" [14 }\end{array}$ & $\begin{array}{l}\text { In this } \\
\text { of thinki }\end{array}$ \\
\hline .V. Brushlinsky & $\begin{array}{l}\text { "Thinking acts, first of all, as a process, i.e. as } \\
\text { something becoming, forming, developing, never } \\
\text { fully completed in its discovery of more and more } \\
\text { properties and relationships of an object [15]. }\end{array}$ & $\begin{array}{l}\text { The emphasis on the dynamic nature of thinking } \\
\text { is important. Based on this definition, it can be } \\
\text { concluded that reproductive learning methods do } \\
\text { not contribute to the development of thinking. }\end{array}$ \\
\hline
\end{tabular}

Table 3

Auxiliary concepts that reveal the essence of the concept of "critical thinking"

\begin{tabular}{|c|c|c|}
\hline \multicolumn{2}{|c|}{ Critical thinking process } \\
\hline Knowledge & Rating & Making decisions \\
Problem & Analysis & Solution to the problem \\
Hypothesis & Argumentation & Reflection \\
\hline
\end{tabular}

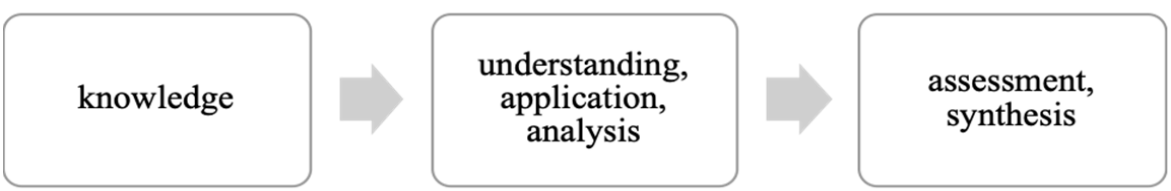

Figure 1. Stages of critical thinking development technology 
Conclusions. Thus, we can conclude that, organizing the study of new material, the teacher proceeds from the principle of the appropriateness to select means and methods of teaching. If the material is difficult for students to perceive or has little reliance on the stock of their knowledge, then its lecture presentation is necessary. But, using a lecture as a methodological device within the framework of this technology, it should be built on a problem-based basis with the involvement of graphic, audio and video information, directing the mental activity of students.

The study of the essence of the concept of critical thinking based on the analysis of domestic and foreign publications revealed terminological problems that are caused by different approaches to the study of this issue.

Based on the data obtained on the implementation of technologies for the development of critical thinking in the educational process, it can be concluded that this technology is in demand. But one cannot fail to note the necessity to develop a system to use techniques for developing critical thinking in the framework of different subject areas, taking into account the specifics of the discipline being taught.

\section{References:}

1. Bibler V. (1975) Thinking like creativity. Moskow, $397 \mathrm{p}$

2. Kant I. (1999) Criticism of Pure Reason. Moskow: The science, $655 \mathrm{p}$.

3. Freud S. (1989) New introductory lectures on psychoanalysis. Norton, $253 \mathrm{p}$.

4. Dewey D. (1997) Psychology and pedagogy of thinking. Moskow: Perfection, $208 \mathrm{p}$

5. Rock D. (2018) Your Brain at Work. Alpina Pablisher, 234p.

6. Rogers, C. (1989) Client-centred / person-centred approach to therapy. Boston: Houghton Mifflin Co, p. 135-152.

7. Vygotsky L.S. (2010) Pedagogical psychology / ed. V.V. Davydova. Moskow: Astrel, 671 p.

8. Popper K. (1983) Logic and the growth of scientific knowledge. Moskow: Progress, $605 \mathrm{p}$.

9. Zaire-Bek S.I. (2011) The development of critical thinking in the lesson: a manual for teachers of educational institutions. Moskow: Education, $223 \mathrm{p}$.

10. Popper K. (2007) Oracle Philosophy and Rebellion Against the Mind. A reader in philosophy: textbook. Allowance. Moskow: TC Velby, Prospect, pp. 394-399.

11. Frankl V. (1990) Man in search of meaning. Moskow: Progress, $366 \mathrm{p}$.

12. Ozhegov S.I. (1973) Dictionary of the Russian language. Moskow: Publishing house "Soviet Encyclopedia"; 846 p.

13. Philosophical Dictionary (1991) / ed. I.T. Frolova. Moskow: Politizdat, $560 \mathrm{p}$

14. Kojaspirova G.M. (2005) Dictionary of pedagogy. Moskow: ICC "Mart", 448 p.

15. Sutherland J. (2017) Scrum: The Art of Doing Twice the Work in Half the Time, Mann, Ivanov and Ferber, 272 p.

16. Konversky A.E. (2017) Logic. Kyiv: HCW "Kyiv University", $391 \mathrm{p}$.

17. Tyaglo O.V. (2008) More critical. Kharkiv: View. group "Basis", $189 \mathrm{p}$

18. Karamisheva N.V. (2000) Logic. Fiduciary for studentlawyer. Lviv: View of the Lviv University, $193 \mathrm{p}$.

19. Lytvynenko A.O. (2018) Setting up a centered approach in the process of managing a company. Theory and practice of ordinary psychology, no. 3, pp. 39-42.

20. Fedorov, A. V. (2007) The development of critical thinking in media education: basic concepts. Innovations in Education, no. 4, pp. 30-47.

21. Zhurin A.A. (2004) Media education is not the lessons of the natural science cycle. Natural History at School, no. 5, pp. 23-27.
22. Selevko G.K. (1998) Modern educational technology: a training manual. Moskow: Public education, $256 \mathrm{p}$.

23. Konversky A.€. (2018) More critical. Kyiv: Center for Educational Literature, $344 \mathrm{p}$.

24. Khomenko I.V. (2010) Logic: theory and practice. Kyiv: Center for Educational Literature, $400 \mathrm{p}$.

25. Karamisheva N.V. (2011) Logic (Theoretical and Applied) First-hand companion. Kyiv: Knowledge, $455 \mathrm{p}$.

26. Hofreiter T.D. (2007) Teaching and Evaluating Critical Thinking in an Environmental Context. Applied Environmental Education and Communicatio, no. 6 (2), pp. 49-157.

\section{Бібліографрічний список:}

1. Библер В. Мыслить творчески. Москва, 1975. 397 с.

2. Кант И. Критика чистого разума. Москва : Наука, 1999. 655 с.

3. Фрейд 3. Новые вводные лекции по психоанализу. Нортон, 1989. 253 с.

4. Дьюи Д. Психология и педагогика мышления. Москва : Совершенство, 1997. 208 с.

5. РокД. Ваш мозг в действии. Альпина Паблишер, 2018. 234 с.

6. Роджерс К. Подход к терапии, ориентированный на клиента / человека. Бостон : Houghton Mifflin Co, 1989. С. $135-152$

7. Выготский Л.С. Педагогическая психология / под ред. В.В. Давыдова. Москва : Астрель, 2010. 671 с.

8. Поппер К. Логика и рост научного знания. Москва : Прогресс, 1983. 605 с.

9. Заир-Бек С.И. Развитие критического мышления на уроке: Учебное пособие для учителей образовательных учреждений. Москва : Просвещение, 2011. 223 с.

10. Поппер К. Философия оракула и восстание против разума. Читатель по фрилософии: учебник. Пособие. Москва : ТЦ Велби, проспект, 2007. С. 394-399.

11. Франкл В. Человек в поисках смысла. Москва Прогресс, 1990. 366 с.

12. Ожегов С.И. Словарь русского языка. Москва : Издательство «Советская энциклопедия», 1973. 846 с.

13. Философский словарь / под ред. Фролова. Москва : Политиздат, 1991. 560 с.

14. Кожаспирова Г.М. Педагогический словарь. Москва : МКЦ «Март», 2005. 448 с.

15. Сазерленд Дж. Скрам: искусство делать двойную работу за половину времени, Манн, Иванов и Фербер. 2017. 272 c.

16. Конверський А. Логіка : підручник. Київ : МО «Київський університет», 2017. 391 с.

17. Тягло О.В. Більш критично : Навчальний посібник. Харків : «Основа», 2008. 189 с.

18. Карамишева Н.В. Логіка. Довірче управління студентуюристу. Львів : Вид на Львівський університет, 2000. 193 с.

19. Литвиненко А.О. Обґрунтування центрованого підходу в процесі управління підприємства. Теорія и практика сучасної психології. 2018. №3. С. 39-42.

20. Федоров А.В. Развитие критического мышления в медиаобразовании: основные понятия. Инновации в образовании. 2007. № 4. С. 30-47.

21. Журин А.А. Медиаобразование - это не уроки естественно-научного цикла. Естествознание в школе. 2004. № 5. C. 23-27.

22. Селевко Г.К. Современные образовательные технологии : учебное пособие. Москва : Народное образование, 1998. 256 с.

23. Конверский А. Критичне мислення. Київ : Центр учебной литературы, 2018. 344 с.

24. Хоменко И.В. Логіка: теорія и практика. Київ : Центр учебной литературы, 2010. 400 с.

25. Карамишева Н.В. Логика (теоретическая и прикладная). Из первых рук. Киев : Знание, 2011. 455 с.

26. Хофррейтер Т.Д. Обучение и оценка критического мышления в контексте окружающей среды. Прикладное экологическое образование и общение. 2007. № 6 (2). C. $49-157$. 